esboços

histórias em contextos globais

\title{
OS PROBLEMAS ESTRUTURAIS DA VIDA COTIDIANA NOS MUNICÍPIOS BRASILEIROS NA PRIMEIRA REPÚBLICA: O CASO DE ALFENAS-MG
}

The structural problems of everyday life in Brazilian municipalities in the First Republic: the case of Alfenas-MG 


\title{
OS PROBLEMAS ESTRUTURAIS DA VIDA COTIDIANA NOS MUNICÍPIOS BRASILEIROS NA PRIMEIRA REPÚBLICA: O CASO DE ALFENAS-MG
}

\section{RESUMO}

Este texto é resultado de um estudo sobre aspectos da vida cotidiana no município de Alfenas durante a Primeira República. No intuito de conhecer alguns dos maiores problemas que afetavam o dia a dia da sua população naquela época e como ela os enfrentava, a análise baseou-se em requerimentos enviados ao poder público municipal. Com isso, o objetivo da investigação é analisar como tais requerimentos podem ser interpretados como instrumentos de ação política, ou de cidadania, por meio dos quais os cidadãos que os assinavam procuravam acionar o poder municipal para solucionar problemas de interesse público.

PALAVRAS-CHAVE: Requerimentos. Cotidiano. Alfenas.

\section{THE STRUCTURAL PROBLEMS OF EVERYDAY LIFE IN BRAZILIAN MUNICIPALITIES IN THE FIRST REPUBLIC: THE CASE OF ALFENAS-MG}

\begin{abstract}
This text is the result of a study that investigated the aspects of daily life in the city of Alfenas during the First Republic. The investigation was based on the requests sent to the city's public power by its citizens, in order to understand some of the major problems affecting the daily life of its population and how it faced them. Thus, the objective of the research is to analyze how such requests can be interpreted as a tool of political action or citizenship through which the citizens who signed them looked forward to engaging the municipal government in the solution of problems of public interest.
\end{abstract}

KEYWORDS: Requests. Daily Life. Alfenas. 
D esde, pelo menos, o fim do tráfico de africanos, em 1850, a sociedade brasileira vinha vivenciando algumas transformações estruturais. Daquele marco cronológico até a Revolução de 1930, a abolição da escravatura na estrutura social, a consolidação do capitalismo na estrutura econômica e a Proclamação da República na estrutura política são os acontecimentos mais marcantes que alteraram a fisionomia do país. Durante a Primeira República (1889-1930), a nova ordem política foi comandada por uma nova fração de classe (uma burguesia ainda influenciada por valores aristocráticos) oriunda da expansão da cafeicultura no sudeste do país durante a segunda metade do século XIX. Seus expoentes promoveram o que se convencionou chamar de modernização conservadora, isto é, uma transformação na organização política e econômica sem mudanças na estrutura social. Para isso, logo após o fim do estado de exceção instaurado pelos militares em 1889, trataram de construir um novo pacto político, conhecido como pacto oligárquico (sustentado na política do café com leite no âmbito federal, na política dos governadores no âmbito estadual e no coronelismo no âmbito municipal), para controlar a máquina do Estado e proteger seus interesses de classe. O estado liberal originado desse pacto não contemplou a grande massa do povo. Este, "bestializado", continuou entregue à sua própria sorte, às suas solidariedades mútuas, ao que sobrou da sensibilidade religiosa, expressa na caridade pública, ou à dádiva dos protagonistas da situação política local, ancorada no paternalismo, agora na sua manifestação coronelista. ${ }^{1}$

Nesse contexto, a macroeconomia da Primeira República ainda estava estruturada nos moldes da economia colonial. O seu principal setor produtivo (fora a produção, com sua dinâmica própria, voltada para o abastecimento interno) estava orientado para a exportação de produtos primários. Consequentemente, quase toda a política econômica nacional girava em torno dos interesses dos seus produtores ao ponto de, quando a demanda de café (o principal produto) diminuía e os seus preços caíam, o governo federal desvalorizar o câmbio para manter o lucro do setor. Inclusive, firmou-se um acordo em 1906, o Convênio de Taubaté, no qual era estabelecido que os maiores estados cafeicultores (São Paulo e Minas Gerais, principalmente) deveriam comprar o excedente produzido para evitar a queda do valor do produto no mercado externo, usando empréstimos estrangeiros (pagos com dinheiro público, o que implicava a socialização das perdas) com o aval do governo federal (desde Afonso Penna). Isso gerou dois efeitos econômicos negativos. O primeiro foi a inflação. De um modo geral, o preço artificialmente alto do café acabava arrastando consigo os preços de outros setores produtivos, inclusive os dos gêneros básicos da alimentação. O segundo foi o aumento da dívida pública. Muitas

\footnotetext{
${ }^{1} \mathrm{O}$ coronelismo foi um fenômeno político resultante da "superposição de formas desenvolvidas do regime representativo a uma estrutura econômica e social inadequadas”, na qual o poder público ainda era frágil demais para prescindir do poder privado dos potentados locais para se impor à população (NUNES, 1997, p. 40). Um de nossos mais eminentes historiadores, Sérgio Buarque de Holanda, já em 1936, em sua clássica obra Raízes do Brasil, afirmava: "É curioso notar que os movimentos aparentemente reformadores, no Brasil, partiram quase sempre de cima para baixo" (HOLANDA, 1997, p. 160). O entendimento da transição política acima referida é tomado de COSTA, 1985, cap. 9. A expressão "os bestializados" foi proferida por um senador contemporâneo da Proclamação da República, Aristides Lobo, e é usada ironicamente por CARVALHO, 1996. Já o conceito de modernização conservadora foi formulado por Moore Jr. (1975) para explicar o modelo de transição política em países como a Alemanha, onde a burguesia se aliou à aristocracia para promover a modernização.
} 
vezes, para administrá-la, emitia-se moeda, o que, normalmente, pelo aumento da circulação de dinheiro sem lastro no crescimento da economia, pressionou a subida dos preços no mercado interno. Desse modo, houve substancial elevação do custo de vida, penalizando duramente a população de baixa renda. Para se ter uma ideia disso, em 1914, o índice do custo de vida no Brasil era 100; em 1919, saltou para 148,8; em 1924, para 236,6; e em 1929, para 261 . $^{2}$

É nesse quadro histórico que serão analisados alguns dos maiores problemas cotidianos da população de Alfenas durante a Primeira República e como ela os enfrentava. Situado no sul do estado de Minas Gerais (MG), esse município foi formado no contexto das oportunidades abertas pela reorientação econômica mineira ocorrida na segunda metade do século XVIII. Seus primeiros colonizadores foram proprietários rurais que buscavam terras para o cultivo de alimentos para subsistência e para os mercados vicinais de uma região então em expansão. A transformação da capital do país em sede da corte portuguesa, inicialmente, e o crescimento da cafeicultura no oeste paulista, posteriormente, ampliaram os horizontes econômicos da elite local (LENHARO, 1979). Dessa maneira, aos poucos, o antigo arraial reuniu condições para tornar-se município (1860) e, já nas primeiras décadas da República, era dotado de um núcleo urbano onde diversos ícones da modernidade estavam presentes: cinema, teatro, luz elétrica, posto de gasolina, fábricas e até uma escola de formação superior, a Escola de Farmácia e Odontologia de Alfenas, criada em 1914, que acabou sendo transformada em universidade federal em 2005.

\section{Suporte teórico e base empírica}

Para mostrar que os requerimentos podem ser interpretados como instrumentos de ação política, ou de cidadania, por meio dos quais os cidadãos que os assinavam procuravam acionar o poder municipal para solucionar problemas de interesse público, muito contribuirão as reflexões de Agnes Heller sobre a vida cotidiana. Segundo ela, esta encontra-se "no centro do acontecer histórico", tornando-se, assim, "a verdadeira essência da substância social, pois "as grandes ações não cotidianas contadas nos livros de história partem da vida cotidiana e a ela retornam" e o seu caráter histórico só pode ser considerado

como tal "graças ao seu posterior efeito na cotidianidade". Em outras palavras, o cotidiano é uma temporalidade estruturada, pois as ações rotineiras que marcam o dia a dia das sociedades são resultado das estruturas sociais. Mas ele também é estruturante, pois é nele também que a estruturação que dá sentido à vida diária é modificada, reestruturada, como resultado dos efeitos imprevistos da sua própria dinâmica ou da possibilidade de os indivíduos tomarem consciência de seus problemas e da sua capacidade de agir para enfrentá-los (HELLER, 1985, p. 20).

O conceito de cultura formulado por Clifford Geertz também será útil neste estudo para a compreensão da vida cotidiana, uma vez que, de acordo com tal autor, "acreditando, como Max Weber, que o homem é um animal amarrado a teias de significados que ele mesmo teceu", ele assume "a cultura como sendo essas

\footnotetext{
${ }^{2}$ Esta síntese foi elaborada a partir de FERREIRA; ALMEIDA, 2003; FURTADO, 2000; PRADO Jr., 1995; e SAMIR, 1976. Os dados sobre custo de vida apresentados foram produzidos por Roberto Simonsen e reproduzidos por FAUSTO, 1972, p. 94.
} 
teias". Desse modo, a cultura é considerada um contexto, algo dentro do qual a ação humana, em suas mais diversas manifestações, pode ser compreendida como um signo. Ora, o significado desse signo dependerá das suas conexões com o contexto no qual está inserido e com a multiplicidade de estruturas que possibilitaram a sua ocorrência (GEERTZ, 1978, p. 15).

Em síntese, as proposições teóricas de Agnes Heller e Clifford Geertz contribuirão, respectivamente, para entender o cotidiano como temporalidade estruturada e estruturante e a cultura como contexto que, no caso que nos ocupa, dava sentido aos problemas que afetavam o dia a dia dos indivíduos alfenenses e às maneiras como eles os enfrentavam.

A documentação que fornecerá as informações para este estudo é composta por requerimentos nos quais os cidadãos solicitavam às autoridades do legislativo ou do executivo decisões destinadas a solucionar problemas de interesse público que precisavam da autorização ou da intervenção institucional. Foram consultados 1.256 requerimentos. Quase todos apresentam elementos da vida cotidiana, mas foram selecionados somente aqueles onde há evidência de dificuldades enfrentadas pela população no dia a dia, sendo 68 ao todo.

\section{Os problemas cotidianos}

Um dos grandes problemas cotidianos enfrentados pela população de Alfenas foram os surtos inflacionários que encareciam o custo dos alimentos acima dos limites suportáveis para quem era pobre, como na conjuntura econômica dos anos do governo Arthur Bernardes (1922-1926). O país não ia bem. A eleição presidencial havia gerado grande desgaste no pacto oligárquico, ampliando as tensões políticas de uma sociedade já bastante tensa politicamente desde o final da época imperial. Em meio a isso, cresciam os movimentos de contestação política, sobretudo das classes médias, motivados pela crise financeira que assolava o país (devido à superprodução de café e ao acúmulo de dívidas para financiar os seus excedentes cada vez maiores). O mais grave desses movimentos, as revoltas tenentistas, iniciadas em 1922, culminou na Coluna Prestes (cujo objetivo era semear a revolução pela nação) e criou um clima de grande tensão nacional.

Para piorar as coisas, as contas públicas não iam bem. No dia 27 de fevereiro de 1925, o general Isidoro Dias Lopes, considerado moderado, enviou uma carta ao deputado federal Azevedo Lima, fazendo o seguinte comentário a esse respeito: "Fantasticamente rico, o Brasil, sob o ponto de vista financeiro, está falido. Não pode pagar os fabulosos juros da sua fabulosa dívida, apesar dos milhões de contos de réis extorquidos do povo nestes últimos 20 anos" (FAUSTO, 1972, p. 94). A política de valorização artificial do café pela compra dos seus excedentes com financiamento estrangeiro havia ido longe demais. A emissão de moeda para rolá-la pressionou a inflação. Consequentemente, o custo de vida durante o governo Bernardes saltou de 184, quando ele assumiu a presidência em 1922, para 260 no final do seu mandato. A situação estava dramática. Incentivados pela garantia de preço do principal produto de exportação brasileiro, muitos agricultores passaram a investir na cafeicultura, produzindo alimentos básicos apenas para consumo próprio. Começou a faltar comida, apesar de o Decreto presidencial n. 16.419, editado em 19 de março de 1924, ter ameaçado com desapropriar terras para a produção de alimentos. Por esse 
motivo, aquele general, na mesma carta, comentou: "O operariado e uns 30 milhões de espoliados, sem dinheiro de ordem alguma, estão quase na miséria, por uma artificial e criminosa carestia de vida" (FAUSTO, 1972, p. 95).

O exposto acima evidencia que a situação beirava a catástrofe. Consequentemente, os preços de quase tudo, em particular dos alimentos, estavam, na maior parte do país, pela hora da morte. E, em Alfenas, as coisas não foram diferentes. Para se ter uma noção disso, um morador da freguesia de São Joaquim da Serra Negra, no dia 18 de outubro de 1924, enviou ao poder legislativo local um protesto bastante esclarecedor a respeito do que se passava no município:

Excelentíssimo Senhor Presidente e demais membros da Câmara Municipal de Alfenas. Eduardo Daniel Ferreira Dias, professor, brasileiro, residente nesta Freguesia, por si e como representante da população pobre da sede, vem à presença da ilustrada Câmara protestar contra a enorme exportação de suínos e cereais para outros municípios circunvizinhos, deixando esse abuso formidável os habitantes de São Joaquim sem recursos e alimentos. A comprovação deste fato está no elevado preço aqui atingido os gêneros de primeira necessidade: a saca de arroz de 58 quilos a $90 \$ 00$ e $100 \$ 000$, feijão a $55 \$ 000$ e $60 \$ 000$ o alqueire de 40 litros (mal medido), toucinho a $38 \$ 000$ a arroba e, ainda a ser encontrado à venda, ao passo que, diariamente, seguem para a Estação grandes partidas em prejuízo do povo. O comércio é livre, mas tem seus limites na proibição de certos abusos, como este. Por que em zonas menos produtivas, como Barro Preto, encontram-se gêneros pela metade ou terça parte do preço? Espera o suplicante que a Câmara não deixará de tomar providências, à semelhança do Rio, São Paulo, Bahia, Pernambuco, Belo Horizonte, etc., crescendo impostos pesados àqueles que na ganância de grandes lucros não se incomodam com a fome e a miséria do povo. ${ }^{3}$

O protesto informa que a saca de arroz de 58 quilos passou a custar entre $90 \$ 00$ e 100\$000; a de feijão, entre 55\$000; o alqueire de 40 litros (mal medido), e 60\$000; e o toucinho saltou para $38 \$ 000$ a arroba. No entanto, os salários não acompanharam a depreciação da moeda. Um condutor de mulas, por exemplo, recebia pelo seu trabalho em Alfenas a quantia de $100 \$ 000$ (cem mil réis) mensais, valor médio recebido pela maioria das pessoas que atuavam em atividades consideradas braçais ou rústicas. ${ }^{4}$

Normalmente, não houve crise de oferta de alimentos. Como o documento acima testemunha, parte considerável da produção votada à subsistência se beneficiava dos altos preços que outras praças comerciais estavam dispostas a pagar por ela, principalmente aquelas eminentemente organizadas para o cultivo de café. Como o município em estudo estava conectado, por meio de uma vasta rede urbana, ao

\footnotetext{
${ }^{3}$ Prefeitura Municipal de Alfenas (PMA) 34.1, Requerimentos 1909-1924.

${ }^{4} \mathrm{O}$ valor dos salários no período pode ser consultado nos livros de despesa PMA 9.2 (1922) e 9.4 (1923 a 1925). A precarização das condições de vida dos trabalhadores na Primeira República é bastante conhecida graças a estudos como os de PINTO (1994, cap. 2); VISCARDI (2011); CHALHOUB (2008); PATTO, (1999); RAGO (1997); e DECCA (1987).
} 
noroeste paulista, onde estavam situadas cidades como Campinas e Ribeirão Preto, as suas colheitas, em grande parte tradicionalmente voltadas para o abastecimento interno desde pelo menos a instalação da corte portuguesa no Rio de Janeiro, podiam facilmente ser escoadas, via ferrovia, para as grandes áreas cafeeiras, onde não se produziam gêneros de primeira necessidade suficientes para o abastecimento próprio.

Assim, os preços do mercado local tendiam a acompanhar os mesmos valores pagos pelos consumidores de municípios mais prósperos, cujas economias eram mais complexas, maiores e fortemente influenciadas pela cafeicultura, para o desespero da parte da população que não tinha outra forma de se abastecer a não ser indo ao comércio.

Ainda em relação à produção de alimentos, outro problema enorme foram as pragas que devastavam as plantações. Em uma sociedade essencialmente rural, como a brasileira da Primeira República, cuja economia estava organizada estruturalmente em torno da agricultura, insetos como as saúvas, reputadas como exímias cortadeiras, constituíam grande ameaça. Uma passagem da clássica obra Triste fim de Policarpo Quaresma (1911), escrita por Lima Barreto, ilustra o drama dos agricultores. A propriedade de Quaresma começava a apresentar seus primeiros resultados para a grande satisfação do dono. Mas a sua alegria durou pouco. "Um inimigo apareceu inopinadamente, com a rapidez ousadíssima [...]. Naquela manhã, quando contemplou o seu milharal, foi como se lhe tirasse a alma [quando viu sua plantação devastada pelas formigas]; ficou sem ação e as lágrimas lhe vieram aos olhos". A reação de Quaresma não poderia ter sido diferente, pois era como "um suplício, um castigo". Diante de tamanho infortúnio, ele percebeu "que só uma autoridade central, um governo qualquer, ou um acordo entre os cultivadores, podia levar a efeito a extinção daquele flagelo, pior que a saraiva, que a geada, que a seca, sempre presente" (BARRETO, 1997, p. 104-105).

Trata-se de um problema antigo. Desde os primórdios da civilização, as formigas sempre foram a mais implacável das pragas devoradoras dos plantios, chegando a representar um obstáculo ecológico capaz de colocar em xeque o processo de sedentarização iniciada com a revolução agrícola há mais de dez mil anos (DIAMOND, 2013).

No Brasil, dada a tradicional forma de preparar os terrenos para o plantio, baseada na coivara indígena, quer dizer, na prática de botar fogo no terreno para facilitar e acelerar a sua limpeza, os predadores naturais das saúvas acabam sendo afugentados. Por isso, a quantidade de formigueiros aumentava, alastrando-se pelos campos. Como são extremamente eficientes na sua organização social e bastante disciplinadas, elas podiam devastar uma plantação inteira da noite para o dia devido à sua voracidade e capacidade de transportar o produto saqueado dos homens em tempo hábil (DEAN, 1996, p. 124-126).

O impacto causado pelas formigas foi tanto que, em diversos municípios, os vereadores tiveram de tomar medidas para combatê-las (SILVA, 2007). Em Alfenas, por exemplo, a Câmara votou uma lei (a de número 286, editada em 28 de julho de 1922, conforme registro no livro de Decretos e Leis) que determinava o seguinte:

Artigo $1^{\circ}$ - Os formigueiros existentes nos quintais ou chácaras particulares serão extintos pela Câmara, quando encontrados em visita domiciliaria pelo fiscal, indenizando os respectivos proprietários as despesas que se fizerem, e os existentes em 
terrenos públicos às expensas do município. Parágrafo único: Se o dono do prédio não consentir na extinção do formigueiro, impedindo a entrada no prédio para esse fim, será multado em 100 mil réis. Artigo $2^{\circ}$ - As pessoas reconhecidamente pobres terão gratuidade para a extinção dos formigueiros [...]. Os operários pagarão o custo da extinção dos formigueiros por prestações arbitradas pelo Agente Executivo. ${ }^{5}$

Certa vez, em 21 de janeiro de 1929, como o problema parecia ultrapassar os limites toleráveis de convivência tensa com as formigas, 27 pessoas assinaram um requerimento cobrando do poder legislativo condições para a aplicação da referida lei.

Os infra-assinados, moradores nesta cidade, considerando que
se torna inadiável uma providência de caráter oficial que possa,
senão extinguir, ao menos diminuir os calamitosos efeitos
causados pelos inúmeros formigueiros disseminados por toda
área urbana da cidade e seus arredores, vem solicitar de Vossas
Excelências um atencioso estudo desse momentoso problema.
Não ignoram Vossas Excelências que em nossa cidade, tão pobre
de recursos, ninguém pode ter o gosto de tratar, com resultado,
de um jardim, de uma pequena horta ou de uma fruteira! O próprio
jardim público sofre sistemática e periodicamente, os duros
efeitos das podas extemporâneas que Ihe infligem as formigas
das circunvizinhanças! Existindo, no entanto, entre as leis de
Alfenas, a de ${ }^{\circ}$ 286, que parece resolver satisfatoriamente as
necessidades locais, os peticionários desejam que ao Sr. Agente
Executivo sejam facultados os meios legais para que a referida
lei entre em pleno vigor. ${ }^{6}$

Trata-se de uma espécie de declaração de guerra. Com o avanço do conhecimento químico e das ciências agrárias, surgiram poderosíssimos defensores agrícolas controladores das pragas que devastavam a base da alimentação humana. Mas, enquanto tal novidade ainda era uma possibilidade teórica, os insetos, em particular as formigas, causavam enormes danos às plantações, criando um problema de grandes proporções para a subsistência e colocando a população em alerta constante para impedir que elas invadissem seus terrenos. Para isso, usavam diferentes métodos pouco eficazes, como colocar formicida nos formigueiros, inundá-los com água, entupi-los com cal, etc. Quando tais métodos falhavam, contratavam uma espécie de exterminador de formigas, como Francisco Batistelli, que, usando "máquinas com ótimos aparelhos e preparados", oferecia seus serviços ao custo de $10 \$ 000$ por formigueiro.

Além dessa catástrofe ecológica, fruto em grande parte do desequilíbrio ambiental provocado por uma técnica antiga ainda em uso no Brasil daquele tempo (a limpeza dos terrenos com fogo), havia também aquelas causadas pela natureza, como as geadas e doenças que atacavam os rebanhos. Às vezes, os efeitos dessas calamidades eram tão funestos que criavam sérias dificuldades, como, por exemplo,

\footnotetext{
${ }^{5}$ Câmara Municipal de Alfenas (CMA) 18.1, p. 156-157.

${ }^{6}$ PMA 34.4, Requerimentos, 1909-1949.
} 
a diminuição de serviços em toda a cadeia produtiva agrícola, afetando gravemente quem dependia dos bons êxitos das safras para o seu sustento e o de suas famílias. Para se ter uma ideia do problema, no dia 20 de janeiro de 1919, 20 carreiros assinaram um requerimento destinado ao presidente e demais membros da Câmara Municipal de Alfenas no qual pediam que não aumentasse o imposto anual da sua atividade profissionacom as seguintes justificativas:

Os abaixo-assinados, moradores neste distrito são todos lançados no orçamento de receita dessa Câmara no imposto de carro de boi, vêm reclamar contra o acréscimo feito pela lei municipal recentemente posta em execução e que aumenta dez mil reis e passou pela dita lei a ser trinta mil réis. Os reclamantes ponderam a essa Câmara que o aumento acima referido veio em época por demais inoportuna, como procuram em seguida demonstrar. As geadas do ano findo, se não extinguiram, ao menos diminuíram sensivelmente a produção de café desta zona, e aquele produto é o elemento principal de vida dos carretos. Acresce ainda que a peste aftosa quase destroçou as boiadas, agravando a situação geral dos reclamantes e a importação do comércio local tem diminuído extraordinariamente, o que produz enorme decréscimo de serviços. ${ }^{7}$

As enchentes também provocavam muitos transtornos na vida cotidiana. Quando chovia demais, as precárias pontes que transpunham a imensa região rural do município acabavam caindo, e as estradas, muitas delas improvisadas, estreitas e de terra batida, ficavam intransitáveis. Isso dificultava a circulação de pessoas e mercadorias entre o campo e a cidade, acarretando prejuízos e desabastecimento sempre que as chuvas precipitasem com demasiado excesso. Essa situação fez com que 113 pessoas, no dia 20 de novembro de 1921, requeressem à Câmara o reparo de um trecho de uma estrada importante, ao que parece, para a rede comercial do município.

Em consequência das grandes chuvas de há um mês mais ou menos, a estrada que liga Alfenas e Areado a Botelhos, a muitos bairros populosos e a diversas fazendas, ficou, no lugar defronte a fazenda de minha propriedade danificada, pelo rombo de açudes e grande acúmulo de água em córregos vizinhos. Assim, esse trecho, aliás não muito grande, impede inteiramente o trânsito. Venho por isso solicitar de Vossas Excelências os favores da Câmara de Alfenas, no sentido de ser com brevidade consertado o referido trecho de estrada, indispensável aos lavradores e comerciantes das circunvizinhanças. ${ }^{8}$

Demandas como essa eram bastante comuns. A região do sul de Minas Gerais, onde está situada Alfenas, apresenta um índice pluviométrico alto. Além disso, seu território é bastante recortado por inúmeros riachos, cujas calhas, geralmente

\footnotetext{
${ }^{7}$ CMA 34, 1892-1919, avulsos sem paginação.
}

${ }^{8}$ PMA 34.2, Requerimentos, 1921. 
pequenas e assoreadas, não suportam o gigantesco volume de água que é despejado abruptamente em seus leitos durante a estação chuvosa. A solução, normalmente, é aumentar o número de calhas, como propuseram à Câmara, no dia 12 de outubro de 1924 , os fazendeiros vizinhos a um rio que provocava muito dano aos seus interesses.

Excelentíssimo Senhor Presidente e demais membros da Câmara Municipal de Alfenas. Não é preciso encarecer as vantagens da desobstrução do Rio São Thomé que tanto estão exigindo o aproveitamento dos terrenos marginais com as culturas de arroz, forragens e outras que se prestam, e a boa conservação das estradas que atravessam ou coleiam aquela torrente, cujas enchentes incalculáveis danos e prejuízos causam todos os anos. E por que fale muito aos interesses de uma das partes mais importantes do município - a extensa zona que compreende o distrito de Serrania, os bairros dos Souzas, dos Vieiras, do Gambá, Muzambo, Campo Redondo, Cariocas, e que é ainda cortada pelas estradas de Divisa Nova e Areado recém abertas para trânsito de automóveis - se julgam os abaixo-assinados, com o direito de dirigir um apelo ao espírito esclarecido dos dignos representantes do povo alfenense, pedindo voltem as suas vistas para um remédio tendente a solucionar tão relevante problema. É de atender-se que as despesas que se impõem não atingirão grande cifra, [...] e propõem os signatários desta a pagarem pela metade o custo do trabalho na extensão em que o rio atravessa as propriedades que lhes pertencem. Não importa isso senão um desejo de cooperar com a administração municipal, que tem sido solicita em atender aos magnos problemas que se ligam à grandeza e à prosperidade de município. Daí por que não se deve esperar senão um gesto de fidalguia de quem sabe compreender as necessidades e remover os tropeços que entravam o desenvolvimento da indústria agrícola, fúrcula em torno do progresso de todos os povos. ${ }^{9}$

Se, por um lado, as enchentes causavam grande embaraço para a circulação de pessoas e mercadorias, por outro, a falta de maior número de estradas e pontes que pudessem interligar os diversos distritos de Alfenas, principalmente entre as áreas produtoras de gêneros de primeira necessidade e os mercados onde eles eram consumidos, dificultava ainda mais as conexões territoriais dentro de um município enorme. Tratava-se de um problema que provocava grandes transtornos para a vida cotidiana da população da época; uma população em franco crescimento devido à expansão econômica municipal, que atraia cada vez mais pessoas de outras regiões seduzidas pelo progresso local. Reclamações a esse respeito eram constantes. Por exemplo, no dia 22 de setembro de 1912, diversos moradores de uma área comercial, que se identificaram não somente pelos seus nomes, mas também pela suas ocupações (Vicente Lemonte - fábrica de manteiga; Moreira e Companhia - comissões e consignações; Manoel Carlos de Menezes - casa de pensão; Figueiredo Magalhães - comissões e consignações; Jonas Paulino Horta -

\footnotetext{
${ }_{9}^{9}$ PMA 34.1, Requerimentos, 1909-1924.
} 
máquina de beneficiar café; Bento Luz Alves - comerciante de gêneros; José Pedro Martins - casa de pensão), requereram da Câmara "ruas para trânsito de veículos", alegando que só existia no bairro onde atuavam profissionalmente "a rua Oriente macadamisada", na qual era "proibido transitar carros de boi", sendo "a maior parte do transporte feito nesses carros". ${ }^{10}$

Muitas vezes, esse problema motivava a ocorrência de conflitos entre as pessoas que precisavam passar por determinados caminhos em direção a distritos onde escoavam a sua produção e se abasteciam de produtos necessários à sua subsistência e à de suas famílias e para a manutenção de suas propriedades. Isso aconteceu diversas vezes. Em uma delas, 44 fazendeiros assinaram um requerimento, no dia 20 de maio de 1924, pedindo ao agente executivo municipal providências contra um transtorno provocado por um cidadão dono de uma propriedade por onde passava um curso de água. Eis a versão deles:

\begin{abstract}
Os abaixo-assinados, fazendeiros e proprietários, moradores nos bairros dos Esteves, da Ponta Alta e do Cascalho vêm trazer ao conhecimento de Vossa Excelência que há muito estão sofrendo prejuízos e delongas no trânsito que fazem pela estrada que desses bairros conduz ao distrito de Fama, para onde quase todos os signatários desta levam o leite que fornecem à fabrica de Celestino Piazza e de onde trazem grande quantidade de produtos de que necessitam para suas lavouras. O embaraço que sofrem resulta do fato de um dos proprietários marginais de um córrego, que é atravessado por essa estrada nos fundos da casa de Francisco José da Silveira, não consentir que o mesmo córrego seja esgotado, chegando a ousadia de tal proprietário a entulhá-lo com estacas e represas, sem utilidade alguma visível ou de utilidade apreciável. A estrada em questão dá trânsito habitual a todos os signatários desta; deve pois ser considerada caminho público, conforme os artigos 225 e 226 dos estatutos municipais vigentes. Vêm portanto pedir a Vossa Excelência sirva-se providenciar no sentido de não ser dificultado ora adiante o trânsito da mesma estrada e de serem respeitados os reparos que na mesma têm sido feitos pelos interessados na sua conservação. ${ }^{11}$
\end{abstract}

Pelo próprio testemunho dos requerentes, percebe-se que a estrada tinha sido improvisada em um terreno particular e que, para os interessados poder usá-la, precisavam da boa vontade do proprietário de outro terreno. Isso revela o descompasso entre a infraestrutura local e as necessidades cada vez maiores de uma população economicamente em expansão. Assim, alguns indivíduos, atentos às urgências do progresso e sabendo das limitações do poder público para investir em obras de ligação viária, geralmente muito caras, procuraram investir nisso para satisfazer seus interesses comerciais; foi o caso de Opympio de Souza Macedo. Este cidadão, no dia 25 de julho de 1924, propôs à municipalidade, por meio da Câmara, a construção, à sua custa, "de uma estrada de autoviação, da Rede Sul Mineira até a

\footnotetext{
10 PMA 34.1, Requerimentos, 1909-1924.
}

11 PMA 34.1, Requerimentos, 1909-1924. 
Fazenda da Correnteza, em caminho para Conceição Aparecida e Carmo do Rio Claro, em divisas do Município de Alfenas e Carmo do Rio Claro, e mais tarde ligando-a a Alfenas e outras localidades circunvizinhas". Para tanto, pediu "o privilégio de 15 anos de isenção de imposto, para só o suplicante ter direito de fazer trafegar caminhões e auto-ônibus durante o referido prazo, podendo passear qualquer particular, a juízo da Câmara, com automóveis". ${ }^{12}$

Três dias depois do envio dessa proposta, o poder legislativo local a deferiu, entendendo que se tratava de um fator de progresso e desenvolvimento para o município. Mas iniciativas como essa foram raras. Exceto por um ou outro potentado local que não estava disposto a esperar que o poder público tomasse as devidas providências, ávido para concretizar um empreendimento ou para explorar um pedágio, quase mais ninguém ousava construir estradas, pois eram investimentos que demandavam vultosos recursos. Consequentemente, os problemas dessa natureza continuaram por longos anos até a era do desenvolvimentismo impulsionar a construção de estradas pelo país atendendo aos apelos da indústria automobilística. Mesmo assim, sabemos o quanto a malha rodoviária nacional é deficitária e, em geral, muito mal conservada até hoje.

Um dos elementos mais importantes - se não o principal - para a vida humana é o acesso à água potável. A sua falta é um dos maiores problemas da vida cotidiana, pois causa inúmeros embaraços no dia a dia, inclusive a proliferação de doenças. No meio rural, normalmente, quando não havia mananciais nas propriedades, furavam-se poços artesianos. Mas, no meio urbano, as coisas eram um pouco diferentes, pois, dadas as dimensões normais dos terrenos, nem sempre era possível construir esses poços e, quando era, o custo era muito alto para a maioria dos habitantes. Aqueles com maiores recursos solicitavam do poder executivo a canalização de água até suas residências. Mas a maioria ia buscá-la nos chafarizes. Com o crescimento da cidade, tal elemento era cada vez mais demandado, e os cidadãos pressionavam o governo local para que tomasse medidas destinadas a satisfazer as suas necessidades em relação aos recursos hídricos. Foi o que fizeram 22 pessoas no dia 22 de março de 1929. Elas argumentaram que havia muito tempo estavam "lutando com dificuldade devido à falta de água" na rua onde residiam, sendo "a maior parte dos moradores sem recursos para fazerem cisternas, por isso pediam a gentileza de mandar colocar uma torneira na rua que segue a Conferência de São Vicente de Paulo". ${ }^{13}$

Em um dos distritos de Alfenas, um cidadão, Benjamim Libânio, viu nesse problema uma grande oportunidade. Ele teve a ideia de montar um empreendimento empresarial que pudesse levar água tratada às residências. Para tanto, precisou solicitar uma concessão da Câmara, à qual enviou um requerimento no dia 14 de outubro de 1924 com os seguintes argumentos irrefutáveis, que lhe valeram o deferimento do seu pedido:

O abaixo-assinado vem requerer a Vossas Excelências Ihe seja concedido ou a empresa que organizar um privilégio de 25 anos para instalação, uso e gozo de serviço de abastecimento de água na sede do distrito de Serrania. Espera o signatário ser

\footnotetext{
12 PMA 34.1, Requerimentos, 1909-1924.
}

${ }^{13}$ PMA 34.4, Requerimentos, 1928-1929. 
bem acolhido por Vossas Excelências o seu pedido, de acordo com as condições juntas a este, tendo em vista a necessidade premente de ser solucionado de vez o problema de abastecimento de água de Serrania. Não querendo por não ser preciso falar sobre as vantagens desse melhoramento, da necessidade que sente nossa população de já numerosa do precioso líquido, convenientemente canalizado, não pode entretanto o signatário deixar de lembrar a essa Egrégia Câmara os numerosos casos de tifo e paratifo, essas duas terríveis entidades mórbidas, que aqui grassam endemicamente, fazendo todos os anos considerável número de vítimas. E essas moléstias aqui surgem devido às águas contaminadas de que se utiliza a grande parte da população. Fazendo tantas vítimas anualmente e sendo certo que a causa, o foco de contágio, reside nas águas que se utilizam os serranienses, urge fazer-se a sua profilaxia. Permitam pois Vossas Excelências, que os próprios serranienses a façam concedendo o privilégio que ora lhes solicito, com o desejo único exclusivo, como vêm da proposta junta, de elevar esta terra a altura que merece e concorrer para o bem-estar da população, principalmente por livrá-la de uma terrível e mortífera endemia. Se aos governos cumpre em primeiro lugar zelar pelo bem-estar e saúde pública, certo fico de que o pedido que por meu intermédio fazem os serranienses há de ser, não padece a menos dúvida, por Vossas Excelências bem acolhido. ${ }^{14}$

Em sua proposta, anexada ao requerimento, cada casa pagaria $5 \$ 000$ de taxa de água, e os edifícios públicos ficariam isentos dessa taxa. Uma das condições para a Câmara deferi-la foi o acréscimo de mais duas obrigações ao concessionário: "Colocar uma torneira no Largo [da Matriz], que somente funcionará em dias de festa, outra funcionando sempre em outro ponto que o Agente Executivo determinar".

Um dos argumentos de Libânio estava fundamentado no saneamento. De fato, desde pelo menos Hipócrates (médico grego da Era Clássica, considerado pai da medicina ocidental), sabe-se que diversas doenças atacam nosso corpo por meio da água. Por essa razão, deve-se ter bastante cuidado com ela, sobretudo ao ser usada para beber ou cozinhar. Quando, no Brasil, aquele cidadão propôs fornecer água tratada à população, fazendo-a chegar até suas casas, seguindo a tendência histórica experimentada pelas nações mais afinadas com a ideia, então em voga, de progresso, vivia-se o que um historiador (HOCHMAN, 1998) chamou de a era do saneamento. A precariedade da higiene pública passou a ser considerada pelas sociedades modernas como um dos grandes problemas cotidianos. Tanto era assim que o Estado brasileiro, influenciado pelas suas elites médicas, já vinha tomando um conjunto de medidas, muitas delas autoritárias, para sanear alguns espaços urbanos da nação desde o início da República. A vacinação obrigatória contra a varíola e a derrubada de moradias populares, como os cortiços, das áreas centrais das cidades consideradas vitrines do progresso nacional são as mais conhecidas.

Nessa época, a saúde estava definitivamente sendo transformada em um bem público, após longa trajetória histórica inaugurada com o lluminismo. Isso porque,

${ }_{14}$ PMA 34.1, Requerimentos, 1909-1924. 
com as Luzes, consolidou-se a visão que considera a doença como um dos maiores entraves à construção de uma sociedade plenamente civilizada e da felicidade dos povos. Influenciados por esse ideário, os governos, nos seus diversos âmbitos, aos poucos foram inserindo o saneamento em sua agenda pública (EUGÊNIO, 2012, p. 87-89). Em Alfenas, por exemplo, várias leis foram editadas pelo legislativo. No dia 27 de outubro de 1912, ficou estabelecida a proibição, "nas torneiras públicas ou particulares, de tirar-se água para fazer barro para muro, adobes, barrear e lavar roupas, etc., sob pena de $10 \$$ a $100 \$ 000 "$. Alguns anos depois, no dia 24 de janeiro de 1918, o agente executivo do município sancionou a seguinte lei: "Todo açougue situado no perímetro urbano, que não reúna as condições de higiene exigidas pela Câmara, e não esteja de acordo com a planta oficial adotada, deve ser modificado dentro do prazo de 90 dias contados da notificação". ${ }^{15}$

Ao mesmo tempo, dada a maior interdependência social incrementada no meio urbano pelo aumento da população e das suas relações econômicas, o medo coletivo das enfermidades aguçou a atenção de muitos indivíduos que tinham assimilado a ideologia da higiene devido à intensa propaganda médica e governamental sobre os perigos de certas práticas culturais.

Uma dessas práticas era a intensa convivência, quase promíscua, com os animais. Como a vida cotidiana ainda era muito dependente deles para o transporte, toleravam-se cavalos, éguas, burros, mulas, atrelados ou não a carroças, e os carros de bois nas cidades. Já os animais de corte, havia muito tempo, desde pelo menos o início do século XIX, não podiam mais ficar soltos nas ruas e, ao longo do mesmo século, nem ao menos podiam ficar no perímetro urbano (EUGÊNIO, 2012, p. 87-89). Mas nem todas as pessoas respeitaram essa proibição. Não era raro ver animais destinados à complementação da subsistência das famílias em quintais situados em áreas urbanizadas, ou mesmo vagando pelas ruas, no tempo da Primeira República. Em Alfenas, João de Castro, fiscal municipal, informou, no dia 05 de fevereiro de 1911, a apreensão de uma cabra às 8 horas da noite, a qual foi recolhida ao curral do Conselho. Como não concordou com a multa imposta por esse fato, o proprietário do animal, José Ferreira de Brito, reuniu dez pessoas que foram com ele até o curral e o soltaram na marra. ${ }^{16}$

Prática igualmente comum, ainda naquele tempo, era a manutenção de chiqueiros em área povoada. Sabe-se o quanto os suínos eram importantes para a alimentação diária. Além de ser um animal de fácil manejo, devido a seu porte, de fácil e rápida engorda e a um custo baixo (da maneira como eram criados: em pequena escala, nos quintais das casas e à base de lavagem), sua gordura era fundamental para as cozinhas de uma sociedade que ainda não podia contar, de maneira acessível ou farta, com o óleo de soja. Assim, para reduzir a dependência do mercado, muitas pessoas ou famílias que tinham espaço suficiente para criá-los montavam pequenas pocilgas para cevá-los. Mas, em plena era do saneamento, esse costume acabou chocando-se com a ideologia da higiene, a qual foi assimilada por muita gente (impossível mensurar a quantidade), como Marieta de Souza Nunes, residente na rua Raul Soares do distrito de Barranco Alto. No dia 19 de outubro de 1929, ela levou ao conhecimento das autoridades públicas municipais o fato de Nicézio Marques

\footnotetext{
${ }^{15}$ CMA 34, 1892-1919, avulsos sem paginação. As referidas leis são, respectivamente, as de n. 6 e 227. ${ }^{16}$ PMA 35, Auto de Infração, sem paginação.
} 
da Costa manter "uma ceva de porcos dentro de seu quintal proximamente da sua propriedade e casa de morada", onde vivia "com cinco crianças". Após relatar essa ocorrência, argumentou que isso "é contra as regras de higiene", razão pela qual pediu para "tomarem providências nesse sentido". ${ }^{17}$

Hoje, esse problema não faz mais parte de nossa realidade. Já o problema da segurança pública, o último a ser retratado neste texto, evoluiu com o tempo, assumindo tamanha proporção que já nos parece incontrolável em face da atual legislação especializada na matéria. Na época da Primeira República, não era menos incômodo. Dadas a enorme exclusão social do período, a proximidade maior da sociedade com a herança escravista, a cultura política autoritária expressa no coronelismo e a fragilidade das leis, a violência já era um mal social muito impactante para a normalidade da vida cotidiana. Ainda não são conhecidos os índices de crimes no município de Alfenas naquele tempo. Mas, usando como indicador a causa das mortes registradas nos livros de sepultamento do seu cemitério público, com um número de assassinatos nada desprezível, pode-se imaginar que aqueles índices não eram baixos. Um dos homicídios foi cometido por Nicésio Domingues da Silva nos idos de 1929. Em sua defesa, argumentou que "uma fatalidade a que não pôde escapar, levou-o a defender-se contra uma agressão que Ihe fez o seu cunhado Francisco Brasilino Terra, produzindo em seu agressor ferimentos que a ele resultou a morte". Como vingança, a família do morto mandou escrever na lápide de sua sepultura quem o havia assassinado, motivo pelo qual, ao considerar tal atitude uma grave ofensa, Domingues da Silva requereu dos poderes públicos locais, no dia 27 de dezembro de 1929, providências contra essa ação. ${ }^{18}$

Esse problema deixa, normalmente, qualquer população muito apreensiva, e isso pode levá-la a pressionar o Estado para que recrudesça sua política de segurança pública, como fizeram dezenas de moradores do distrito de Conceição da Boa Vista. No dia 25 de abril de 1909, eles enviaram o seguinte requerimento, prontamente deferido, para a Câmara:

Os abaixo-assinados, residentes nesta freguesia, não concordando de forma alguma com os abusos e desordens cometidos publicamente pelos ébrios e desordeiros aqui, e não possuindo esta freguesia nem sequer uma pequena custódia para a devida correção; urge pois para a tranquilidade e segurança de nosso lar, irmos à presença dessa digna Assembleia pedir o auxílio de $50 \$ 000$ para a construção de um prédio de 30 por 25 palmos para servir de cadeia pública. Com nossos esforços e o apoio de Vossas excelências, dessa pequena quantia que nada prejudicará os cofres municipais, contamos certo levar a efeito este desideratum. ${ }^{19}$

\section{Conclusão}

A lista de dificuldades que transtornavam o cotidiano em Alfenas, exemplares da realidade brasileira da Primeira República, não se esgota nos problemas acima

\footnotetext{
17 PMA 34.4, Requerimentos, 1928-1929.

18 PMA 34.4, Requerimentos, 1928-1929. Diversos livros.

19 PMA 34.1, Requerimentos, 1909-1924.
} 
apresentados. Os que foram abordados são alguns dos mais incômodos encontrados na documentação, conforme a sua recorrência e a maneira como foram relatados. Resultantes de uma sociedade estruturada cultural, política e economicamente por um liberalismo excludente, por uma mentalidade escravista persistente e pelas limitações materiais derivadas de uma configuração social em processo tardio de modernização (se comparada com as das nações situadas no centro do capitalismo industrial), tais problemas nos mostram não somente as contradições, injustiças e sofrimentos engendrados na sociedade de Alfenas durante a Primeira República, mas também os esforços de uma população empenhada em superar seus embaraços, exigindo dos poderes públicos, ou a eles propondo soluções, por meio de um dos seus instrumentos de ação política, os requerimentos, para que a vida pudesse fluir conforme as suas expectativas de normalidade cotidiana.

\section{REFERÊNCIAS}

BARRETO, Lima. Triste fim de Policarpo Quaresma. Rio de Janeiro: Globo/Klick editora, 1997.

CARVALHO, José Murilo de. Os bestializados: o Rio de Janeiro e a República que não foi. $3^{a}$ ed. São Paulo: Companhia das Letras, 1996.

CHALHOUB, Sidney. Trabalho, lar e botequim. $2^{a}$ ed. Campinas: Unicamp, 2008.

COSTA, Emília Viotti da. Da Monarquia à República: momentos. $3^{a}$ ed. São Paulo: Brasiliense, 1985.

DEAN, Warren. A ferro e fogo: a história da devastação da Mata Atlântica brasileira. São Paulo: Companhia das Letras, 1996.

DECCA, Maria Auxiliadora Guzzo. A vida fora das fábricas: cotidiano operário em São Paulo (1920-1934). Rio de Janeiro: Paz e Terra, 1987.

DIAMOND, Jared. Armas, germes e aço: os destinos das sociedades humanas. $15^{\mathrm{a}}$ ed. São Paulo: Record, 2013.

EUGÊNIO, Alisson. Fontes para o estudo da história de Alfenas. Alfenas: Universidade Federal de Alfenas, 2013.

EUGÊNIO, Alisson. Arautos do progresso: ideário sobre saúde pública no Brasil da época do Império. Bauru, Edusc, 2012.

FAUSTO, Boris. A revolução de 1930: história e historiografia. 2a ed. São Paulo: Brasiliense, 1972.

FERREIRA, Jorge; ALMEIDA, Lucíola de Delgado (orgs.). O Brasil republicano: o tempo do liberalismo excludente. V. 1. Rio de Janeiro: Civilização Brasileira, 2003.

FURTADO, Celso. Formação econômica do Brasil. $27^{a}$ ed. São Paulo: Companhia Nacional/Publifolha, 2000.

GEERTZ, Cifford. A interpretação das culturas. Rio de Janeiro: Jorge Zahar, 1978.

HELLER, Agnes. O cotidiano e a história. $2^{\text {a }}$ ed. Rio de Janeiro: Paz e Terra, 1985. 
HOCHMAN, Gilberto. A era do saneamento. São Paulo: Hucitec, 1998.

HOLANDA, Sérgio Buarque de. Raízes do Brasil. São Paulo: Companhia das Letras, 1997.

LENHARO, Alcir. As tropas da moderação: o abastecimento da corte na formação política do Brasil, 1808-1842. São Paulo: Símbolo, 1979.

MOORE Jr., Barrigton. Origens sociais da ditadura e da democracia. São Paulo: Martins Fontes, 1975.

NUNES, Victor Leal. Coronelismo, enxada e voto. $3^{a}$ ed. Rio de Janeiro: Nova Fronteira, 1997.

PATTO, Maria Helena Souza. Estado, ciência e política na Primeira República. Estudos avançados, São Paulo, v. 13, n. 35, p. 167-198, 1999.

PINTO, Maria Inez Machado Borges. Cotidiano e sobrevivência: a vida do trabalhador pobre na cidade de São Paulo. São Paulo: Edusp, 1994.

PRADO Jr., Caio. História econômica do Brasil. 42ª ed. São Paulo: Brasiliense, 1995.

RAGO, Margareth. Do cabaré ao lar. 3a ed. Rio de Janeiro: Paz e Terra, 1997.

SAES, Alexandre Macchione; MARTINS, Marcos Lobato. O sul de Minas em transição: a formação do capitalismo na passagem para o século 20. Bauru: Edusc, 2012.

SAMIR, Almir. Desenvolvimento desigual: ensaio sobre as formações sociais do capitalismo periférico. São Paulo: Forense Universitária, 1976.

SILVA, Valéria Mara da. Nascidas do sol e da chuva: Minas Gerais e o combate às saúvas (1928-1936). 2007. 198 f. Dissertaçã (Mestrado em História). Faculdade de Filosofia e Ciências Humanas, Universidade Federal de Minas Gerais, Belo Horizonte, 2007.

VISCARDI, Cláudia Maria Ribeiro. Pobreza e assistência no Rio de Janeiro na Primeira República. História, Ciência, Saúde-Manguinhos, v. 8, suplemento 1, p. 179-197, 2011.

\section{NOTAS}

Alisson Eugênio: Doutor. Professor, Universidade Federal de Alfenas, Instituto de Ciências Humanas e Letras, Departamento de Ciências Humanas, Alfenas, MG, Brasil. Rua Gabriel Monteiro, 700, 37130000, Alfenas, MG, Brasil. abr., 2019.

\section{FINANCIAMENTO}

Não se aplica.

\section{APROVAÇÃO DE COMITÊ DE ÉTICA EM PESQUISA}

Não se aplica. 


\section{CONFLITO DE INTERESSES}

Não se aplica.

\section{LICENÇA DE USO}

Este artigo está licenciado sob a Licença Creative Commons CC-BY Internacional 4.0. Com essa licença você pode compartilhar, adaptar, criar para qualquer fim, desde que atribua a autoria da obra.

\section{PUBLISHER}

Universidade Federal de Santa Catarina. Programa de Pós-graduação em História. Portal de Periódicos UFSC. As ideias expressadas neste artigo são de responsabilidade de seus autores, não representando, necessariamente, a opinião dos editores ou da universidade.

\section{HISTÓRICO}

Recebido em: 17 de agosto de 2018

Aprovado em: 26 de setembro de 2018 